\title{
Harvesting and Local Knowledge of a Cultural Non-Timber Forest Product (NTFP): Gum-Resin from Boswellia serrata Roxb. in Three Protected Areas of the Western Ghats, India
}

\author{
Kori Veeranna Soumya ${ }^{1,2, * \mathbb{C}}$, Charlie M. Shackleton ${ }^{1} \mathbb{C}$ and Siddappa R. Setty ${ }^{2}$ \\ 1 Department of Environmental Science, Rhodes University, Makhanda 6140, South Africa; \\ c.shackleton@ru.ac.za \\ 2 Ashoka Trust for Research in Ecology \& the Environment (ATREE), Royal Enclave, Srirampura, Jakkur Post, \\ Bangalore 560064, India; siddappa@atree.org \\ * Correspondence: soumyakori89@gmail.com
}

Received: 20 September 2019; Accepted: 14 October 2019; Published: 15 October 2019

\begin{abstract}
Soliga tribes in the Western Ghats, India harvest some NTFPs (non-timber forest products) for religious purposes. They extract gum-resin from Boswellia serrata Roxb. in Biligiri Rangaswamy Temple Tiger Reserve (BRT), Cauvery Wildlife Sanctuary (CWS), and Malai Mahadeshwara Wildlife Sanctuary (MMH) in the state of Karnataka, India. They use gum-resin as a cultural offering to the deities in the temples in these study sites and in their households. The traditional harvesting practices adopted by the Soliga tribes in these protected areas, types of gum-resin extracted, and the nature of the extraction processes were examined. The research undertook 346 household surveys with gum-resin harvesters and non-harvesters across 15 villages, along with 60 field trips with the harvesters, during which field harvesting activities and practices were noted. Six different types of gum-resin were harvested, with marked differences between the three sites. Because of the different types of gum-resin, the quantities harvested were also significantly different between sites. Approximately $80 \%$ of the harvesters were aware of some harmful methods of harvesting gum-resin, and some harvesters highlighted that B. serrata trees would yield gum-resin only when damaged. Such damage could be human-made or through the effects of elephants, wind, Trigona honey harvest, deer horns or body rubbing and longhorn beetles. Most (81\%) of the non-harvesters surveyed previously practiced gum-resin harvesting but had ceased for a variety of reasons, mostly because of insufficient demand and hence income from the sale of gum-resin, insufficient supply, or fear of wild animals in the forests. Considering these cultural practices, experiences, and beliefs of the Soliga communities can help inform management plans and conservation of the species in its natural habitat.
\end{abstract}

Keywords: cultural NTFP; gum-resin; harvesting practice; Indian frankincense; Soliga

\section{Introduction}

Globally, most rural households depend to some degree on wild resources, such as firewood, medicinal plants, wild foods, and construction timber, as contributions to their livelihoods [1-3]. Additionally, wild resources, often termed non-timber forest products (NTFPs), can act as a buffer for rural households to cope during adverse situations such as droughts, floods, crop failure, livestock losses, or death of a breadwinner [4]. This is likely to increase in some regions under increasing climate change impacts [5]. Equally importantly, consumption of and trade in wild resources lowers the 
rural poverty in many regions of the world [6-8], which, under the right conditions, can also prompt resource conservation [9] and support cultural needs [10].

Although many NTFP harvest systems appear ecologically sustainable [11,12], concerns are often voiced about the likelihood and potential impacts of overharvesting. This is because of the multiple uses and dependencies on NTFPs, which if overharvested could jeopardize the livelihoods, incomes, and species populations. The effects of harvesting may also be exacerbated by other stressors, such as climate change, fire, invasive species, or herbivory, further undermining the potential viability of harvested populations $[13,14]$. However, generalizations across contexts and species should be made with caution because the assessment of ecological sustainability must be done at the local scale while taking cognizance of the broader dynamics of the social-ecological system in which harvesting and livelihoods are embedded [12]. A multitude of factors need to be taken into consideration, such as the consequences of long-term NTFP harvest on individual populations, fitness and vigor of the progeny, climate and environmental variability, synergistic or antagonistic stressors, harvest strategies, consumptive demand, trade demand, cultural norms and local or higher scale governance systems [15-17].

Plant exudates like oleo gum-resins such as frankincense, myrrh, and gum-arabic are important NTFPs in many regions; being exploited by the pharmaceutical, pharmacological, traditional medicine, food, dye, flavor, cosmetics, and perfumery industries, and the unprocessed forms are used in religious ceremonies as incense [18]. Gum-resins can be a good source of income to poor and vulnerable communities and hence can contribute significantly to poverty alleviation [19]. Although such exudates have the potential to increase the income of rural households, they are rarely the sole source of income [20], other than for specialist traders. Nonetheless, in some settings they can provide better financial returns to the rural communities than typical agricultural land uses [21,22].

Frankincense is a gum-resin produced by tree species belonging to the genus Boswellia (Burseraceae) [23], of which there are 25 species, found in the dry parts of Arabia, Africa, and Asia $[24,25]$. However, serious concerns abound about the degradation of Boswellia woodlands and Boswellia populations across the globe [26], with calls for urgent conservation and restoration.

A large number of empirical studies have been conducted worldwide on the harvesting of frankincense from Boswellia papyrifera (Del.) Hochst. [27,28], highlighting that it can reduce the number of fruits and viable seeds. In contrast, Groenendijk et al. [29] proposed that the decline of B. papyrifera populations is mainly because of a regeneration bottleneck and adult mortality, which is driven by fire, grazing, and beetle attacks, rather than frankincense harvesting. Alaamri [30] suggests frankincense harvesting techniques from Boswellia sacra Flück. in light of its decline because of drought, habitat loss, and grazing threats. However, a lack of proper harvesting methods was seen as one of the critical challenges undermining the establishment of a viable frankincense industry (based eight different Boswellia species) in the Horn of Africa [31].

The species of interest in the current study is Boswellia serrata Roxb. found in the dry deciduous forests of India and Pakistan [32]. In Sri Lanka, the species is critically endangered or possibly extinct [33]. In India, it occurs in the states of Madhya Pradesh, Jharkhand, Andhra Pradesh, Orissa, Gujarat, Punjab, Assam, Rajasthan, and Karnataka [34]. Boswellia serrata produces gum-resin that is popularly called Indian frankincense or Indian olibanum. The gum-resin from B. serrata is medicinal and is popular among Unani, Ayurveda, and western medicinal practices [35]. Because of overharvesting of gum-resin in Madhya Pradesh, a ban was enacted in 1969 but was later lifted in 2003 [34]. The species is vulnerable in Chhattisgarh, where gum-resin is harvested by the local communities for medicinal purposes [36]. The declines of B. serrata populations in India have affected Boswellia spp. of African origin (e.g., B. sacra, Boswellia neglecta S. Moore., Boswellia frereana Birdw., and B. papyrifera) as buyers are looking for substitutes. Moreover, the primary threat to the species in India is the tapping practice [34].

When burnt the fragrant gum-resin from B. serrata emits a pleasant odour, which is the basis for its use in religious ceremonies [37]. Several of the religious zones in southern India are inside protected areas (PAs) and visited by millions of pilgrims every year [38]. The gum-resin from B. serrata 
is offered to the deities in pilgrim centers in southern Karnataka, especially in the sites considered in this study [39]. With growing religious tourism in southern Karnataka, concerns have been voiced about gum-resin extraction in these regions, especially from PAs in the Western Ghats biodiversity hotspot. Therefore, as part of a broader, local-level sustainability assessment, this study set out to examine the harvesting practices of this cultural resource, i.e., gum-resin from B. serrata in three PAs of the Western Ghats, India. Population status of B. serrata differed across the three PAs [39]. They hypothesized that it may be a consequence of one or more of different ecological settings, extraction rates or harvesting practices. Consequently, this study sought to examine the practices associated with the gum-resin harvest at three PAs, with an emphasis on the types of gum-resin extracted and the nature of the extraction processes.

\section{Materials and Methods}

\subsection{Study Areas}

The study was conducted in three PAs of the Western Ghats, Karnataka, India viz., Biligiri Rangaswamy Temple Tiger Reserve (BRT), Cauvery Wildlife Sanctuary (CWS), and Malai Mahadeshwara Wildlife Sanctuary (MMH) (Figure 1; Table 1). Each PA has several Soliga villages inside, and villagers are allowed to harvest a range of NTFPs. The Karnataka Forest Department (KFD) manages the PAs. Biligiri Rangaswamy temple of BRT, Muthuraya Swamy temple of CWS, and Malai Mahadeshwara temple of MMH are famous temples that draw tens of thousands of pilgrims every year from southern India. There are approximately 50-100 pilgrims visiting the temples in BRT and CWS daily during the week, with 500-800 in MMH, while on weekends the daily numbers are 3-10 times greater. The numbers of pilgrims in $\mathrm{MMH}$ increase during the new-moon day, Mondays, and festivals. The pilgrims offer the gum-resin from B. serrata to the deities and pray for good fortune. Soligas have the rights to harvest gum-resin (locally called dhoopa or cheluge dhoopa) in these PAs and sell it at the temples or use it in their own homes as an offering to the deities or also use it during auspicious ceremonies [39]. The chief sources of income for the Soliga tribes are agriculture, sale of NTFPs, and daily wage laboring [40].

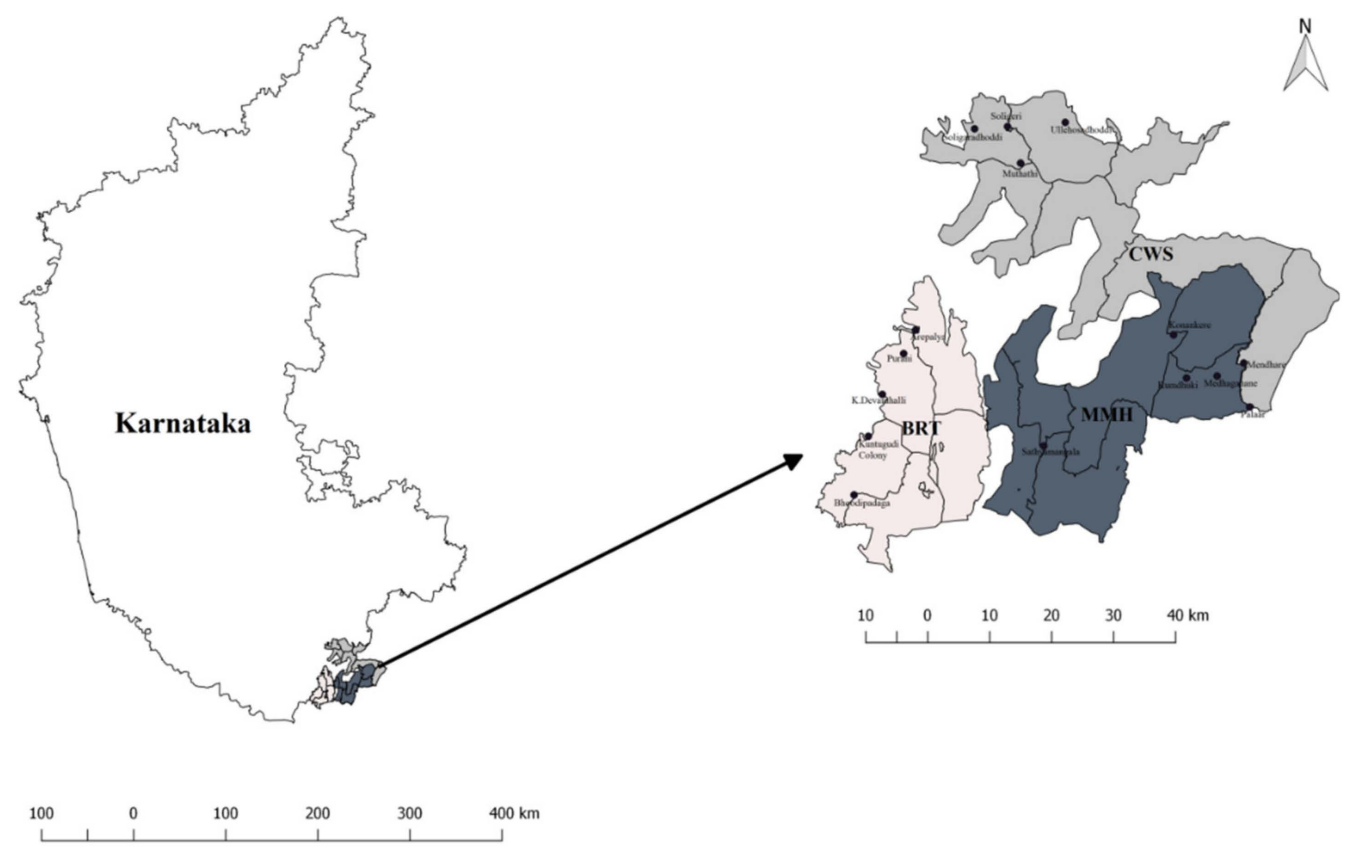

Figure 1. Study sites and sample villages. 
Table 1. Summary study site attributes of the three study protected areas.

\begin{tabular}{cccc}
\hline Study Site & BRT & CWS & MMH \\
\hline Total area $\left(\mathrm{km}^{2}\right)$ & 655 & 1097 & 984 \\
\hline Elevation (m a.s.l.) & $600-1800$ & $250-1500$ & $700-1500$ \\
\hline Annual rainfall $(\mathrm{mm})$ & $900-1800$ & $750-800$ & $600-900$ \\
\hline Temperature range $\left({ }^{\circ} \mathrm{C}\right)$ & $8-38$ & $15-38$ & $15-45$ \\
\hline Forest types & $\begin{array}{c}\text { Scrub, ever-green, } \\
\text { woodland savanna and } \\
\text { deciduous forests }\end{array}$ & $\begin{array}{c}\text { Thorn scrub, dry } \\
\text { deciduous forest, dry } \\
\text { mixed deciduous, } \\
\text { tropical moist deciduous } \\
\text { and bamboo forests }\end{array}$ & $\begin{array}{c}\text { Scrub, dry deciduous, } \\
\text { evergreen and } \\
\text { bamboo forests }\end{array}$ \\
\hline $\begin{array}{c}\text { Human population } \\
\text { (approx.) }\end{array}$ & 12,500 & 450 & 12,000 \\
\hline No. of Soliga villages & 61 & 5 & 30 \\
\hline
\end{tabular}

Biligiri Rangaswamy Temple Tiger Reserve (BRT), Cauvery Wildlife Sanctuary (CWS), and Malai Mahadeshwara Wildlife Sanctuary (MMH).

\subsection{Methods}

A total of 15 Soliga villages were sampled based on their proximity to forests with $B$. serrata, five in BRT, four in CWS, and six in MMH (Figure 1). Data were collected during 2016 and 2017 in each village by means of household surveys with harvesters and non-harvesters, and field trips with the harvesters.

Within each village, a snowball sampling technique was adopted to identify the gum-resin harvesters (a maximum of 20) and non-harvesters (10). The harvester to non-harvester ratio was unknown. There were a total of 346 interviews; in BRT 93 harvesters and 33 non-harvesters, in CWS 65 harvesters and 27 non-harvesters, and in MMH 94 harvesters and 34 non-harvesters. Open-ended questionnaires were used to conduct the surveys. Each lasted for 30-40 min with a harvester and 20-30 min with a non-harvester. The surveys were in the local language (Kannada), after obtaining verbal, informed consent. Preceding the study ethical clearance was obtained from the ethical clearance committees at ATREE and Rhodes University who thoroughly examined the study proposal, consent form, and questionnaires. The questionnaire for harvesters captured details such as harvest season, harvest history, methods of harvest, types of gum-resin harvested, knowledge on the uses of the gum-resin, frequency of harvest trips, quantity of gum-resin harvested per trip, yield from a single tree, location of Boswellia trees, and the impacts of fire, elephants or long-horn beetles on trees. Non-harvesters were questioned about the history of gum-resin harvest, whether they ever had harvested, reasons for terminating harvesting, changes that they expect in gum-resin harvest practices, and whether they thought harvesting gum-resin is harmful to the species.

Complementing the household interviews were 60 trips (2-4 trips per village; 26 in BRT, 15 in CWS and 19 in $\mathrm{MMH}$ ) with harvesters to observe and discuss harvest practices and knowledge. Harvesters usually went in pairs, and thus we interacted with 119 harvesters during the 60 field trips; 51 in BRT, 31 in CWS, and 37 in MMH. Each trip spanned 4-5 hours, timed between beginning the walk from the village to the harvesting sites and return to the village. We noted any tools carried by the harvesters, the type and weight of gum-resin harvested from each tree during the trip, the number of trees scanned for the availability of gum-resin, time spent during each trip and on each tree to harvest gum-resin, and the DBH and height of the trees from which gum-resin was harvested. We also noted the methods of harvest and any type of damage resulting in gum-resin yield, approximate age of the damage (according to the harvesters), and intensity of damage (height*length*depth of each wound) per tree. 


\subsection{Data Analysis}

All the data collected from the household surveys and field trips were entered into MS-Excel and analyzed using program R [41]. Chi-square tests were used to examine the differences between the three study sites with respect to categorical variables. A principal component analysis (PCA) was used to explore any association between the socio-economic characteristics of harvesters and frequency of gum-resin harvest, type of gum-resin harvested, and study sites. Continuous data were examined using the non-parametric Kruskal-Wallis test because many variables were not normally distributed. Generalized linear regression tests the differences in the means, conditional on distributional assumptions, the theta parameter, and the covariates. The data was not normally distributed and as we did not have a single covariate to draw conclusions we considered Kruskal-Wallis test to examine the continuous data. Pairwise tests for multiple comparisons were made using the post-hoc Dunn test [42].

\section{Results}

\subsection{Profile of Harvesters and Non-Harvesters}

One-third (32\%) of the harvesters were female, ranging from $15 \%$ in BRT to $40 \%$ in $\mathrm{MMH}$ and $45 \%$ in CWS. The age of respondents ranged from 18 to 85 years, with an average of $43 \pm 14$. On average, the respondents had $4 \pm 2$ years of schooling, indicating they were mostly illiterate. The respondents were either involved in agriculture on their own lands $(16 \%)$ or on lands owned by others $(19 \%)$ or were daily wage laborers (57\%). A few (3\%) harvesters owned a business or were employed by KFD $(4 \%)$ or by other government agencies.

Similarly, of the 94 non-harvesters interviewed $35 \%$ were females and $65 \%$ were males. Their age ranged from 18 to 86 (average $55 \pm 20$ ). Unlike harvesters, non-harvesters were slightly literate, with an average of $6 \pm 4$ years of schooling. Twenty-eight percent of the respondents were involved in agriculture on their own lands and $23 \%$ on lands owned by others. Eleven percent of the respondents were daily wage laborers, $16 \%$ owned a business or were employed by other government agencies (excluding forest department), and KFD employed 21\%.

\subsection{Harvesting Practices}

The harvest frequency (Figure 2) was significantly higher at MMH than the other two sites $\left(\chi^{2}=96\right.$; $\mathrm{df}($ degrees of freedom $)=16 ; p<0.05)$, where over $40 \%$ of the harvesters went out daily. In contrast, at BRT, most harvesters said they rarely went, mostly when there were unanticipated monetary needs or for special cultural occasions in the family.

The primary season of harvest did not differ across the study sites $\left(\chi^{2}=6 ; \mathrm{df}=10 ; p=0.8\right)$. In MMH and CWS harvesting occurred throughout the year. In BRT the harvesters said that more gum-resin is available from February to May because the gum-resin exudes-after the winds and rains from June to September and dries between October and January. However, they would harvest throughout the year for immediate cash income or household cultural necessities.

The harvest history differed across the sites $\left(\chi^{2}=126 ; \mathrm{df}=12 ; p<0.05\right.$; Figure 3$)$, with more than $50 \%$ of the harvesters in BRT having practiced harvesting since their childhood or since they started going to the forests (the harvesters did not remember their age when they started going to the forests and hence we have considered these responses as "since childhood" or "since started going to the forests"), whereas in CWS and MMH most had been harvesting for less than five years. 


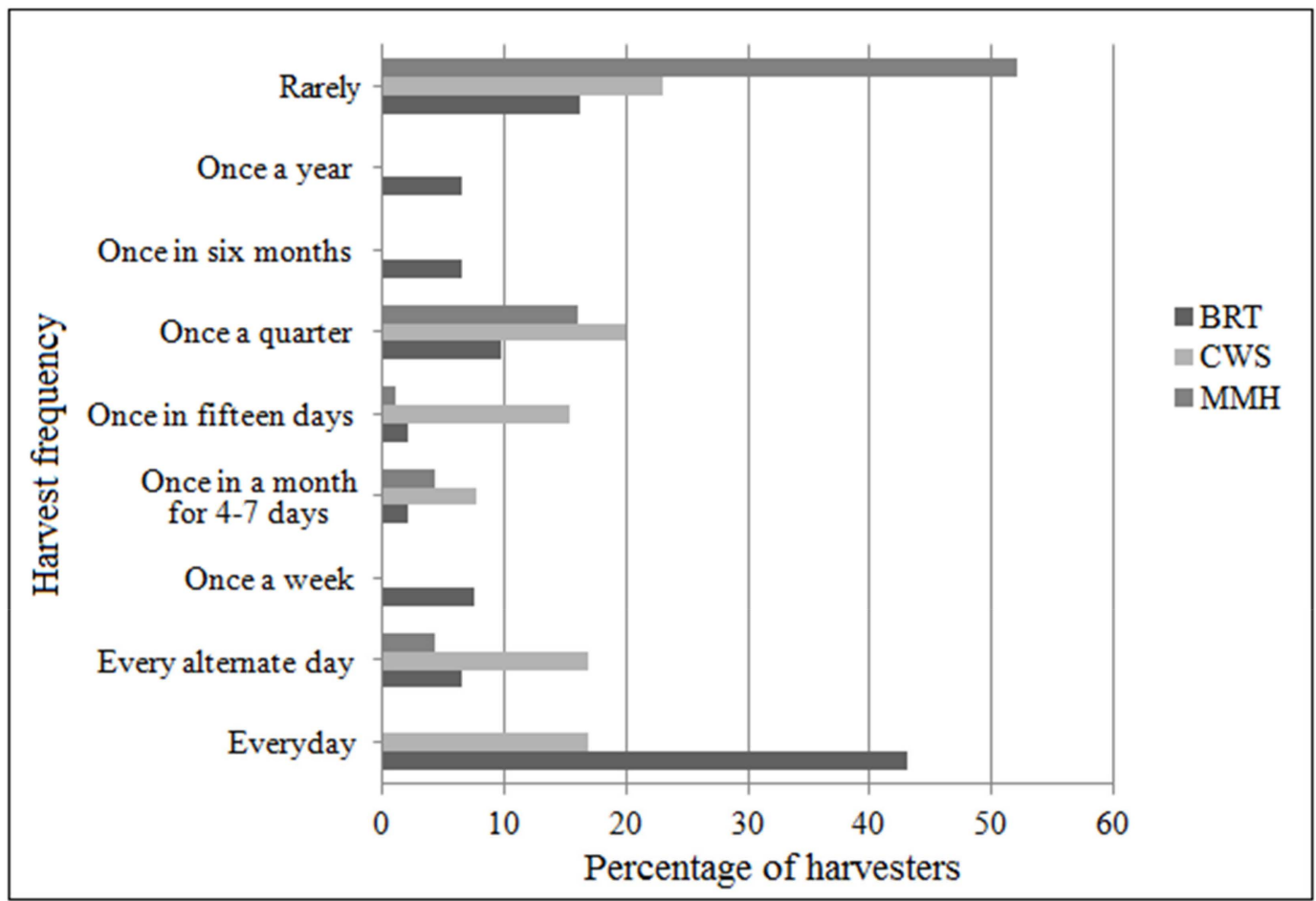

Figure 2. Frequency of $B$. serrata harvest at the three study sites.

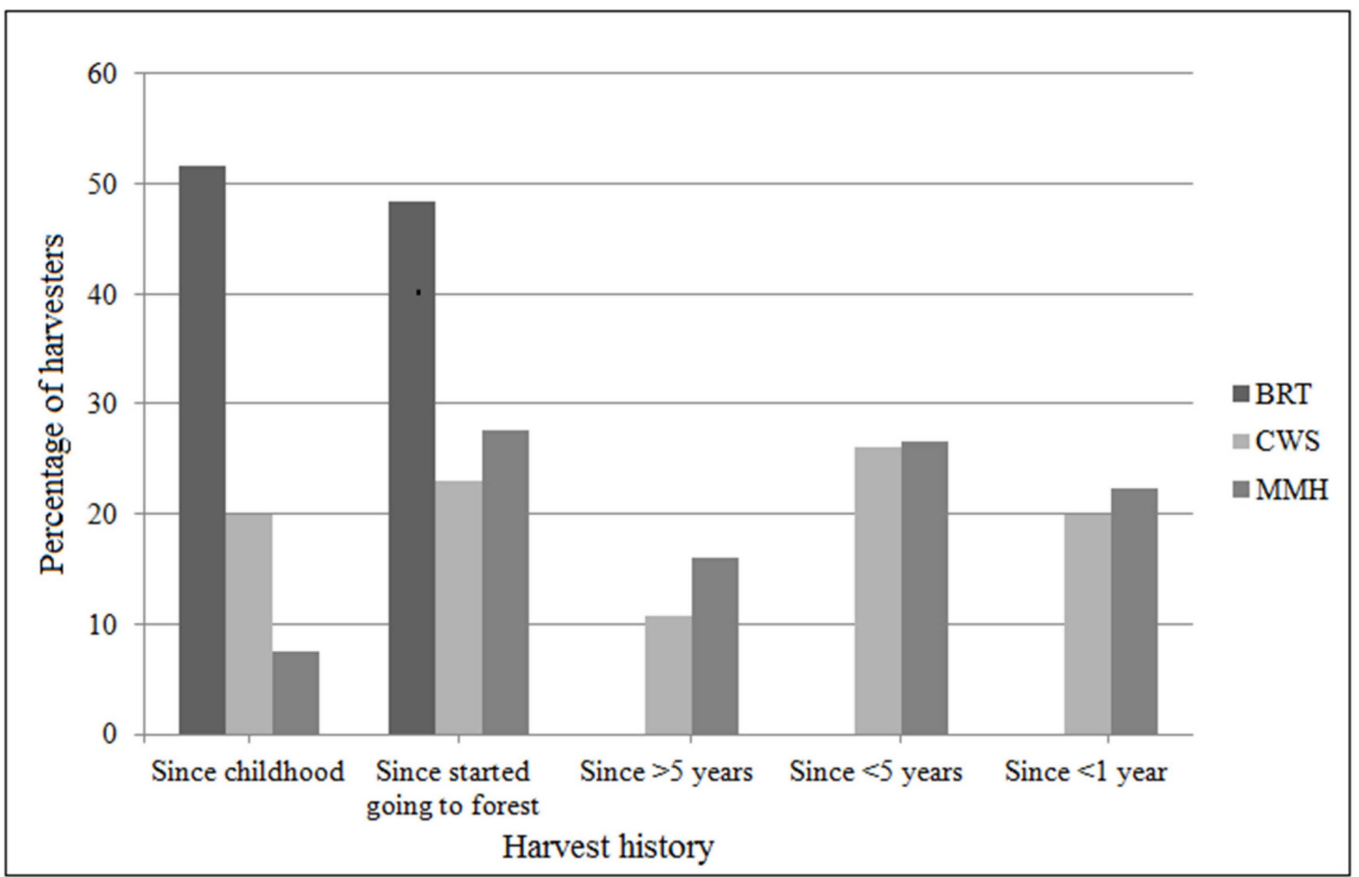

Figure 3. Length of time as a harvester.

There are several different forms of gum-resin from B. serrata based on from where on the tree it is extracted and whether pure or mixed with debris (Figure 4$)$. There were clear differences between the three sites on what forms were favored $\left(\left(\chi^{2}=326 ; \mathrm{df}=10 ; p<0.05\right)\right.$ and consequently the modes of harvesting. In BRT harvesters preferred the pure form of gum-resin (Figure $4 \mathrm{a}$ ) or any gum-resin stuck to the bark, along with the actual bark (Figure $4 \mathrm{~b}$ ), which they removed by either handpicking or scrapping the surface using a machete or an axe. In contrast, at CWS the harvesters handpicked or dug roots with the help of a machete, or wrecking or digging bar to harvest the gum-resin that is 
mixed with soil (Figure 4c). They also harvested longhorn beetle-infested gum-resin (Figure 4d) with a machete or by handpicking. In $\mathrm{MMH}$, they mostly harvested bark scales (Figure 4e) or deadwood containing gum-resin (Figure 4e). Harvesters in CWS and MMH also harvested the pure forms if they found it, and generally used it at home rather than sold it.
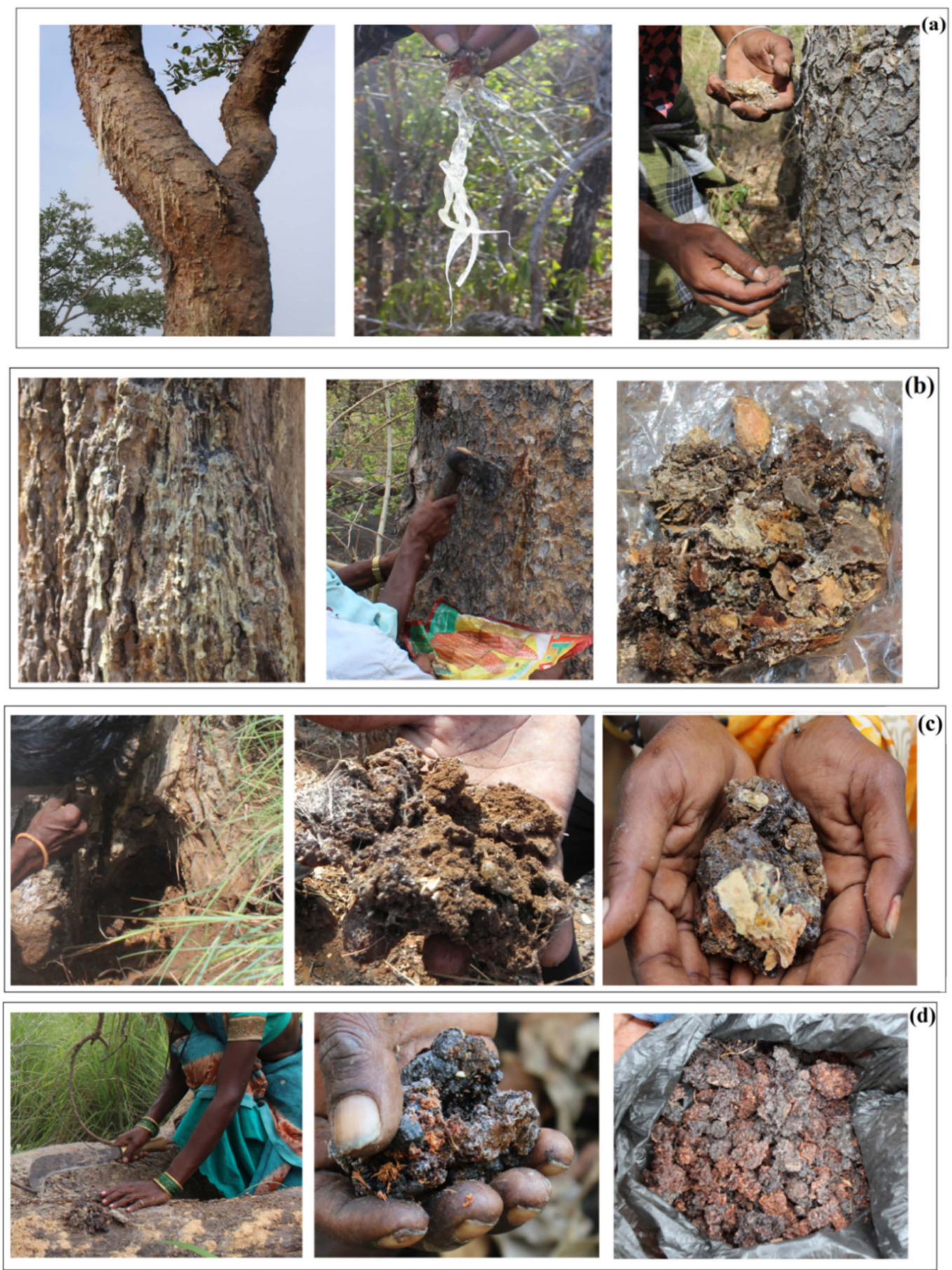

Figure 4. Cont. 

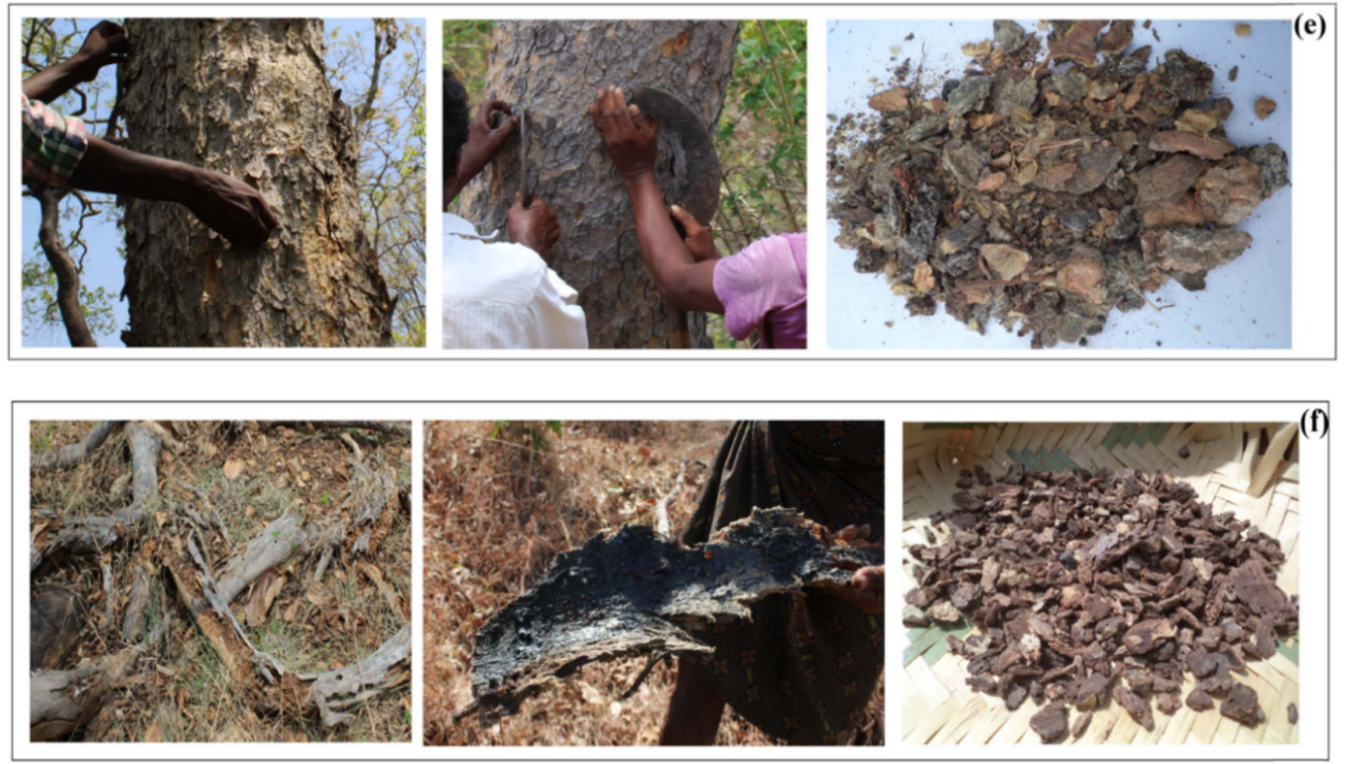

Figure 4. (a) pure gum-resin harvesting, (b) gum-resin stuck to the bark, (c) soil mixed gum-resin, (d) longhorn beetle-infested gum-resin, (e) bark scales, and (f) deadwood.

Because the type of gum-resin harvested differed between the three sites, the quantity of gum-resin harvested by a harvester in a single visit also varied greatly $\left(\chi^{2}=298 ; \mathrm{df}=18 ; p<0.05\right)$. All the harvesters in MMH harvested 1000-10,000 g per trip, whereas $98 \%$ of harvesters in BRT and $88 \%$ in CWS harvested less than $250 \mathrm{~g}$ and 50-2000 $\mathrm{g}$ of gum-resin, respectively. Most harvesters in BRT (86\%) and CWS (85\%) do not separate different types of gum-resin when they are using or selling it, but most (78\%) in $\mathrm{MMH}$ do.

Estimates of the yield of gum-resin harvested from a single tree also varied across the sites because of the different types of gum-resin harvested $\left(\chi^{2}=252 ; \mathrm{df}=4 ; p<0.05\right)$. Fifty-nine percent of harvesters in BRT estimated harvesting 10-50 g (pure, and pure and bark mixed) per tree, whereas $31 \%$ of harvesters in CWS estimated it was 500-1000 g (soil mixed or longhorn beetle-infested) and in MMH 29\% said a single tree could yield 2000-5000 g of gum-resin (bark scales or deadwood) per trees per harvest.

Awareness among harvesters on harmful methods of harvesting differed significantly across the sites $\left(\chi^{2}=157 ; \mathrm{df}=5 ; p<0.05\right)$. In BRT and $\mathrm{MMH}, 81 \%$ of the harvesters mentioned damaging or wounding the tree, while $86 \%$ of the harvesters in CWS highlighted that digging deep into the roots of the tree can be harmful. As bark scales and deadwood was harvested only in $\mathrm{MMH}, 4 \%$ of the harvesters in $\mathrm{MMH}$ said harvesting wet bark scales or cutting the entire tree to harvest dead wood is harmful to the tree.

The PCA (Figure 5) revealed only a weak relationship between type of gum-resin harvested and frequency of harvest. Additionally, both of these were negatively related to annual income and occupation. 


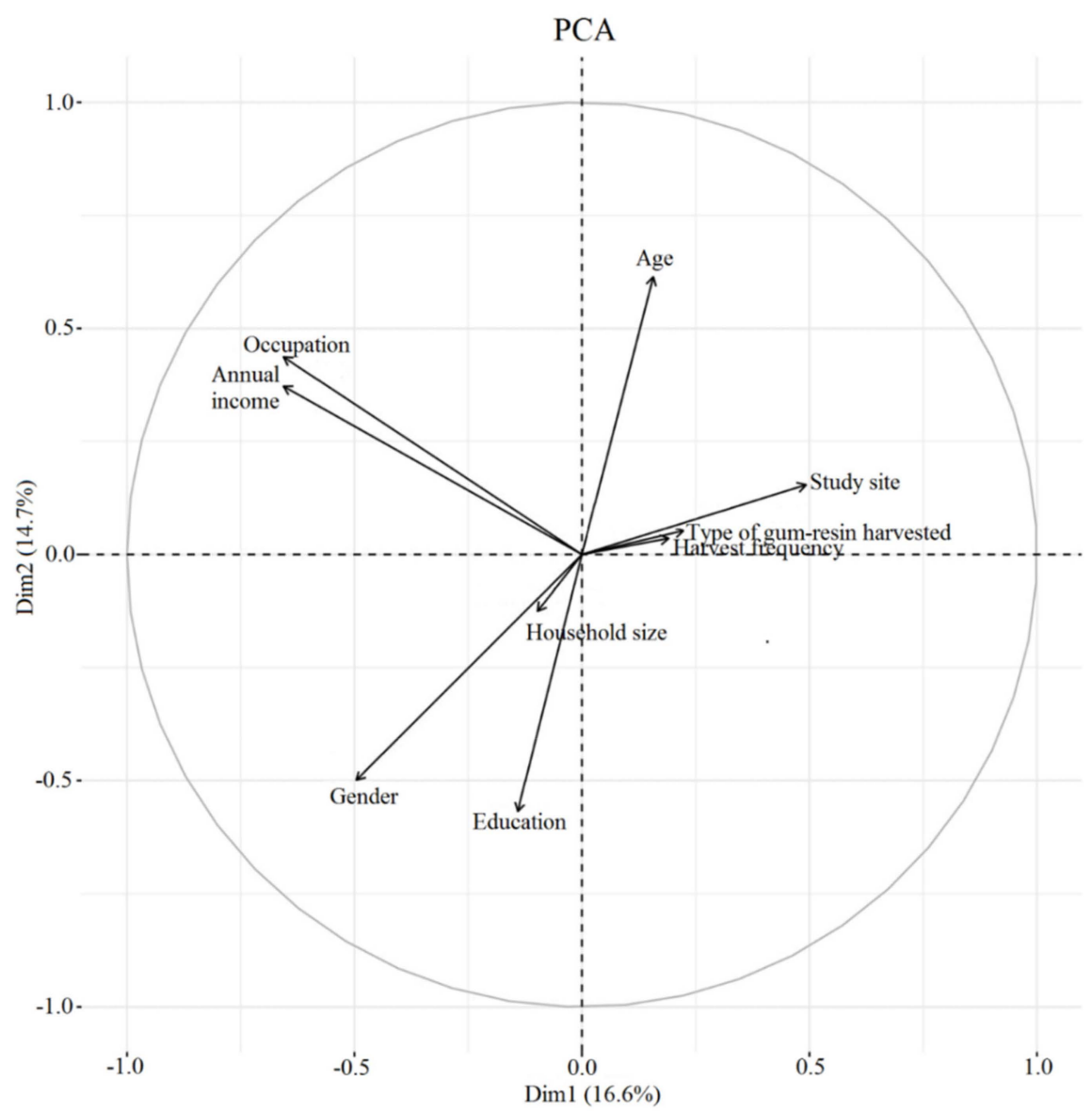

Figure 5. PCA (principal component analysis) demonstrating an association between harvester socio-economic profiles and harvesting practice.

\subsection{Findings from the Harvest Trips}

During the 60 sample field trips, gum-resin was harvested from 310 trees (BRT-133, CWS-81, and MMH-96). Harvesters in BRT and MMH each carried a machete or an axe, while in CWS harvesters carried a machete, an axe or a wrecking, or digging bar. The average length of a harvesting trip was $282 \pm 59$ min. During which time between $190( \pm 67$; BRT), $250( \pm 75$; CWS $)$ and $290( \pm 32 ; \mathrm{MMH})$ trees were scanned for gum-resin. The average DBH of trees from which harvesters harvested gum-resin was $43 \pm 9 \mathrm{~cm}$ and trees were approximately $12 \mathrm{~m}$ tall. The mean amount of gum-resin harvested per tree was $66 \pm 68 \mathrm{~g}$ in BRT, $155 \pm 210 \mathrm{~g}$ in CWS, and $98 \pm 89 \mathrm{~g}$ in MMH irrespective of the type of gum-resin (Table 2). The gum-resin harvested was a product of the type of damage (Figure 6); the damage types were defined by the harvesters and were easily distinguishable in the field. The extent and approximate age of damage on B. serrata trees are presented in Table 3.

The type and weight of gum-resin harvested across the study sites were significantly different $(\mathrm{H}=27.5, p<0.05)$. Multiple pairwise comparisons using post-hoc Dunn test highlighted six of the 21 pairwise comparisons to be significant, notably between BRT, CWS, and MMH. The pairwise comparison between deer horn or body rubbed, and longhorn beetle-infested $(p=0.0045)$, elephant and longhorn beetle-infested $(p=0.0009)$, longhorn beetle-infested and manual $(p=0.0018)$, elephant and wind ( $p=0.0159)$, longhorn beetle-infested and no wound $(p=0.0277)$, and longhorn beetle-infested and Trigona honey harvested $(p=0.0046)$ damages showed significant differences. 
Table 2. Weight (g) of gum-resin harvested from a single tree during harvest trips.

\begin{tabular}{cccc}
\hline Type of Gum-Resin & \multicolumn{3}{c}{ Study Site } \\
\cline { 2 - 4 } & BRT & CWS & MMH \\
\hline Pure form (Figure 4a) & $49 \pm 57$ & $55 \pm 33$ & $20 \pm 7$ \\
\hline Pure + bark mixed (Figure 4a,b) & $50 \pm 51$ & $105 \pm 95$ & $41 \pm 24$ \\
\hline Soil mixed (Figure 4c) & $145 \pm 106$ & $226 \pm 274$ \\
\hline Soil + pure mixed (Figure 4c,4a) & $119 \pm 85$ & $167 \pm 126$ & 0 \\
\hline Soil + bark mixed (Figure 4c,b) & $150 \pm 0$ & 0 & 0 \\
\hline Longhorn beetle (Figure 4d) & $95 \pm 35$ & $285 \pm 477$ & 0 \\
\hline Scaly bark (Figure 4e) & 0 & 0 & $150 \pm 48$ \\
\hline Scaly bark + deadwood (Figure 4e,f) & 0 & 0 & $140 \pm 85$ \\
\hline Deadwood (Figure 4f) & 0 & 0 & $204 \pm 189$ \\
\hline
\end{tabular}

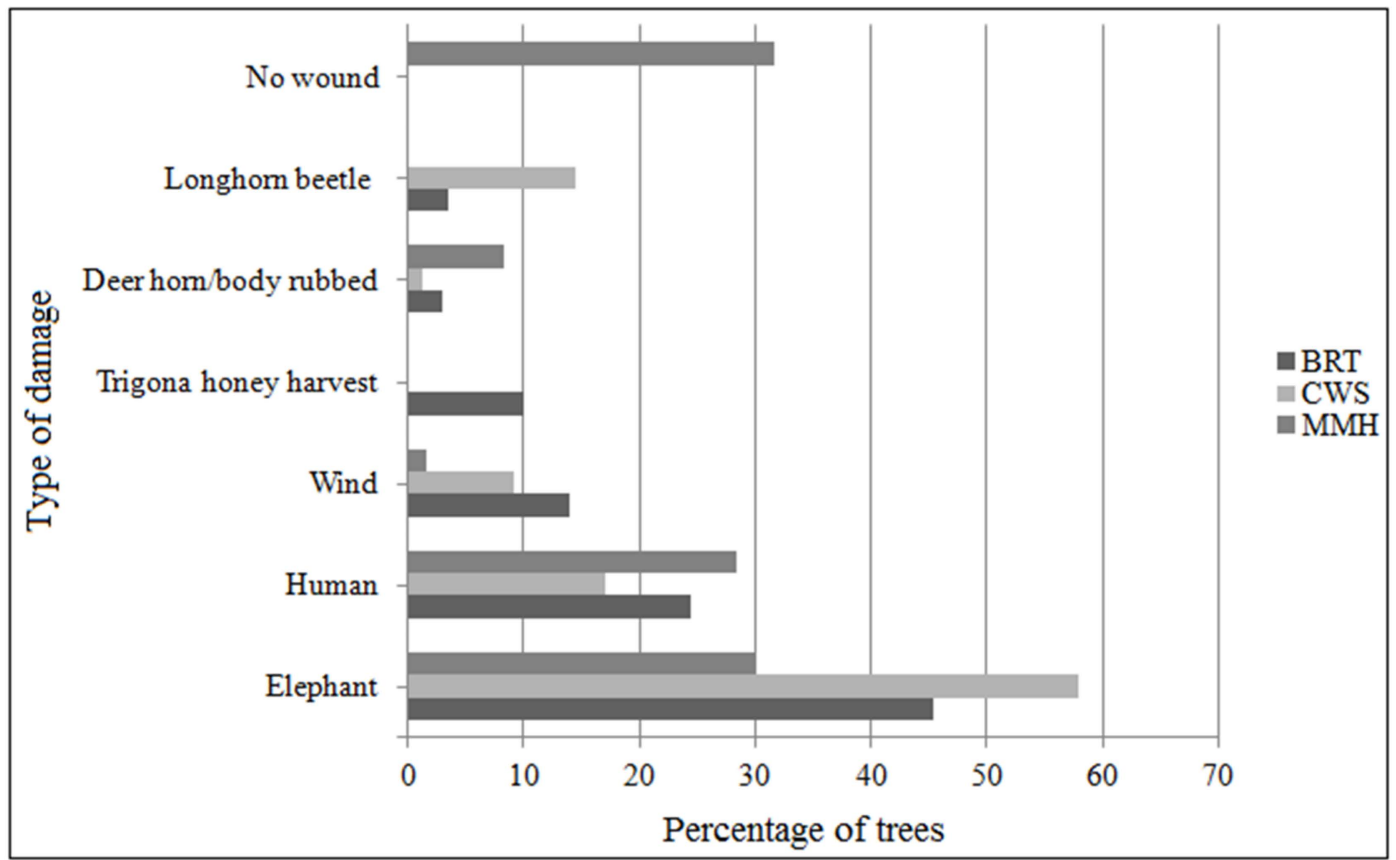

Figure 6. Damage proportions across the study sites observed during harvest trips.

Table 3. Average age (according to the harvesters) and dimensions of different types of damage.

\begin{tabular}{|c|c|c|c|c|c|c|}
\hline \multirow{2}{*}{$\begin{array}{l}\text { Type of } \\
\text { Damage }\end{array}$} & \multicolumn{3}{|c|}{ Age (Months) } & \multicolumn{3}{|c|}{ Extent of Damage $\left(\mathrm{cm}^{3}\right)$} \\
\hline & BRT & CWS & MMH & BRT & CWS & MMH \\
\hline Elephant & $7.3 \pm 7.6$ & $8.3 \pm 9.6$ & $4.3 \pm 2.2$ & $5285 \pm 11,580$ & $6483 \pm 7924$ & $3408 \pm 4618$ \\
\hline Manual & $11.8 \pm 15.3$ & $9 \pm 2.6$ & $2.2 \pm 0.4$ & $4823 \pm 10,637$ & $658 \pm 269$ & $3337 \pm 1633$ \\
\hline Wind & $15.9 \pm 22.8$ & $17 \pm 5.2$ & $8 \pm 0$ & $29,406 \pm 86,297$ & $5930 \pm 12,490$ & $100 \pm 0$ \\
\hline $\begin{array}{c}\text { Trigona honey } \\
\text { harvest }\end{array}$ & $52.5 \pm 33.7$ & - & - & $25,388 \pm 11,178$ & - & - \\
\hline $\begin{array}{l}\text { Deer horn/body } \\
\text { rubbed }\end{array}$ & $18 \pm 16.9$ & - & $1.7 \pm 0.8$ & $344 \pm 148$ & - & $398 \pm 223$ \\
\hline Longhorn beetle & $9 \pm 4.2$ & $12.7 \pm 8.3$ & - & $2384 \pm 1629$ & $23,548 \pm 32,873$ & - \\
\hline
\end{tabular}




\subsection{Knowledge of Gum-Resin Use and Tree Distribution and Damage Agents}

Knowledge of traditional use of the gum-resin did not differ between the sites. All the harvesters across all the study sites were aware of the use of gum-resin as an offering to the deities. Seventy-three percent of harvesters in BRT and $68 \%$ in CWS mentioned that B. serrata trees on the hilltops, exposed to sunlight and wind, yield more gum-resin. In contrast, $62 \%$ of the harvesters in $\mathrm{MMH}$ stated that the location of the tree did not influence the yield of gum-resin. Any minor differences in opinion $\left(\chi^{2}=6\right.$; $\mathrm{df}=6 ; p=0.3)$ are mainly due to the type of gum-resin harvested across the sites. Seventy-six percent of all the harvesters interviewed agreed that older trees yield more gum-resin than the younger trees, while a third ( $37 \%$ ) stated that not all B. serrata trees yield gum-resin. Nonetheless, $29 \%$ said "if there is a wound on the tree it will surely yield gum-resin."

The opinions of harvesters about the impact of fire on the number of trees and gum-resin yield did not vary $\left(\chi^{2}=10 ; \mathrm{df}=8 ; p=0.3\right)$. The harvesters said forest fires would burn dry trees (9\% in BRT, $20 \%$ in CWS and 10\% in MMH) or expose trees to disease/kills the trees (20\% in BRT, $18 \%$ in CWS and $26 \%$ in $\mathrm{MMH}$ ) or that fire enhances gum-resin yield in the short term, but with severe fires a tree will ultimately die in $2-3$ years ( $26 \%$ in BRT, $26 \%$ in CWS and $19 \%$ in MMH). About $30 \%$ of all the harvesters suggested trees resist fire; while $15 \%-20 \%$ of the harvesters had no knowledge about the impact of fire on the number of trees. The perceived effects of forest fires on the yield of gum-resin varied from site to site based on what type of gum-resin the harvester was interested in $\left(\chi^{2}=214 ; \mathrm{df}=6 ; p<0.05\right)$. Sixty-two percent of the harvesters in BRT mentioned positive impacts of fire in increasing gum-resin yield. In contrast, in CWS, $78 \%$ of the harvesters stated that fire negatively impacts the trees and melts any gum-resin. In $\mathrm{MMH}, 71 \%$ of the harvesters highlighted no impact of fire on the species or the gum-resin they harvest.

The impacts of elephants on the populations and gum-resin yield differed based on the type of gum-resin harvested $\left(\chi^{2}=44 ; \mathrm{df}=4 ; p<0.05\right)$. In BRT 53\% and MMH, $91 \%$ of the harvesters said "when elephant damage is severe, the tree oozes more gum-resin and eventually dies." On the contrary, $42 \%$ in BRT and $62 \%$ in CWS said "when an elephant damages the tree, it oozes gum-resin, and the wound heals." In MMH, only 3\% of the harvesters agreed that the damage made by elephants would eventually heal.

The awareness on the impact of longhorn beetle (LHB) on the species or on the type of gum-resin itself was different across the sites $\left(\chi^{2}=33 ; \mathrm{df}=4 ; p<0.05\right)$. Fifty-six percent in BRT and $61 \%$ in $\mathrm{MMH}$ harvesters were unaware of longhorn beetle infestation or its impact. In CWS, $78 \%$ of the harvesters were aware of it, but with little consensus on its effects, such that $22 \%$ said "longhorn beetles kill the tree slowly and the tree dies within 2-3 years of infestation," but $57 \%$ said "nothing happens to the tree."

\subsection{Non-Harvesters}

Most ( $81 \%)$ of the non-harvesters had previously harvested gum-resin at some time (Table 4). The reasons for termination varied across the sites $\left(\chi^{2}=22 ; \mathrm{df}=14 ; p<0.05\right)$, as depicted in Figure 7 . In all the study sites $20 \%$ of the non-harvesters said there is no demand for the kind of gum-resin they harvested, $15 \%$ said the returns were poor, and $28 \%$ said they were scared of elephants or other wild animals. In BRT, $27 \%$ of the non-harvesters informed they would rather buy incense sticks or gum-resin from the market or use gum-resin from other species. In MMH, $24 \%$ of the non- harvesters stated there was not enough of the type of gum-resin they preferred in the forests. 
Table 4. Proportion (\%) of non-harvesters who had previously harvested and time since cessation.

\begin{tabular}{cccc}
\hline Ceased Harvesting & BRT & CWS & MMH \\
\hline Never harvested & 15 & 15 & 24 \\
\hline 1-3 years ago & 36 & 52 & 21 \\
\hline 4-10 years ago & 33 & 19 & 32 \\
\hline$>10$ years ago & 15 & 15 & 21 \\
\hline
\end{tabular}

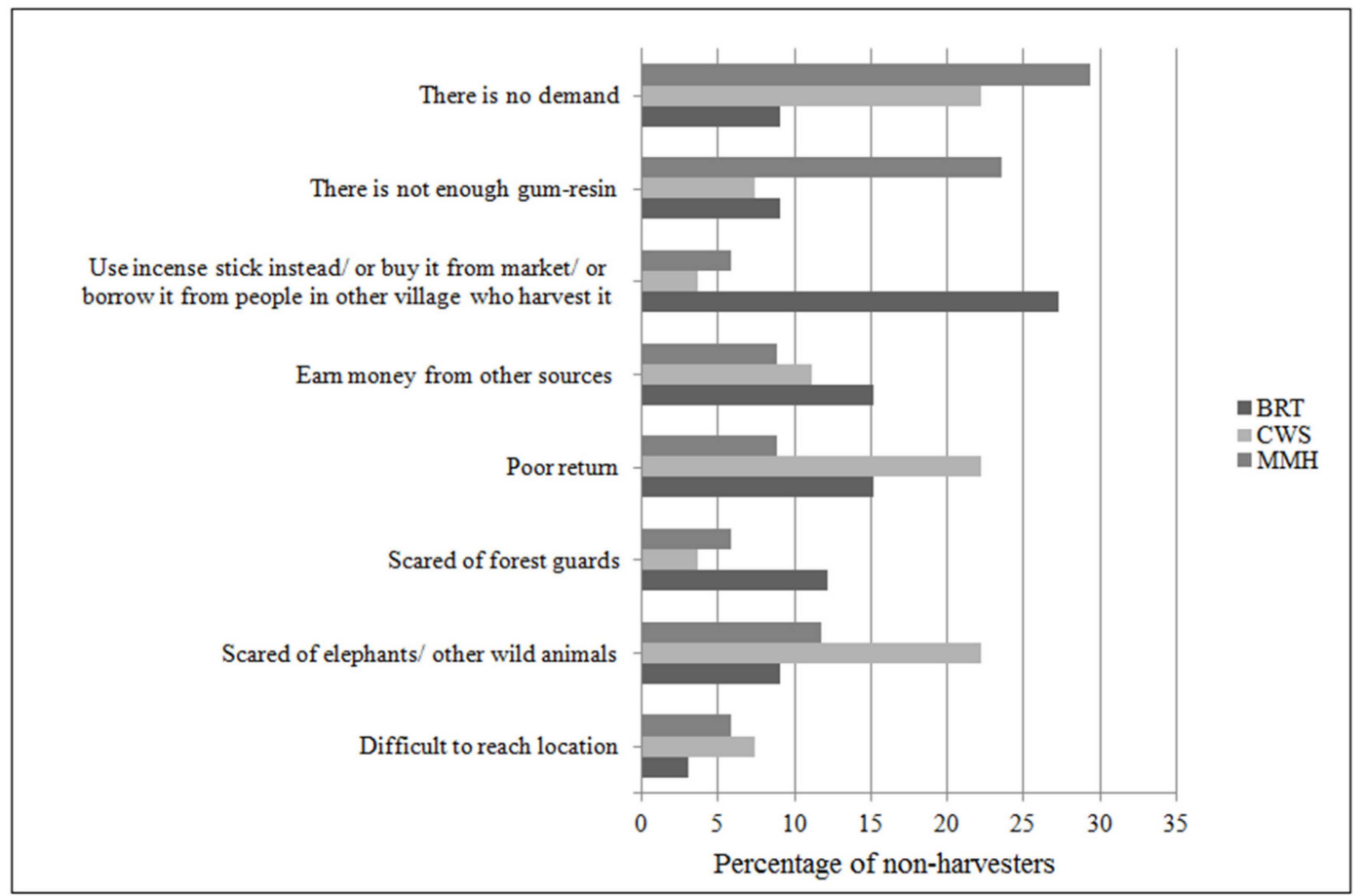

Figure 7. Reasons for not harvesting gum-resin and percentage of non-harvesters across the study sites.

There was a significant difference between sites in the answers from non-harvesters about what changes that they would require to induce them to recommence harvesting $\left(\chi^{2}=30 ; \mathrm{df}=6 ; p<0.05\right)$. Most non-harvesters in BRT (61\%) and CWS (70\%) wanted to see a stable institution to market the product, while $30 \%$ and $74 \%$ of non-harvesters in CWS and MMH, respectively, wished to see no interference from forest officials when they enter forest and harvest gum-resin.

\section{Discussion}

This study sought to understand the harvesting practices associated with the use and trade of gum-resin from B. serrata in the PAs of the Western Ghats. This was encouraged by [34] reporting the market demand for the gum-resin and its derivatives for various purposes in eastern, central, and western India but noting that very little was known about the collection and harvesting practices, which underline sustainability. They also noted a lack of studies from southern India. Furthermore, the work of [39] revealed varying population profiles and growth and mortality rates of B. serrata across the three PAs of this study, which prompted examination of harvesting practices to see what role they might have to play.

The results show some differences between those who harvest and those who do not. On average, non-harvesters tended to be slightly more educated, and have other livelihood options such as farming $(51 \%)$ or in formal employment, than current harvesters. This mirrors findings internationally, as well as within the specific region. The Soliga communities have co-existed with the forest for centuries, and one of their traditional occupations is collecting NTFPs $[43,44]$. However, with the introduction 
of the Mahatma Gandhi National Rural Employment Guarantee Act in 2006 (NREGA 2005), there has been a marked increase in the occupational opportunities in the study areas. Hence, people who have an occupation that serves their livelihood, gravitate toward more financially certain options [45]. Although not a random sample, the results also suggest that harvesting is mostly, but not exclusively, undertaken by males. This is likely to be related to issues of physical safety in the forest with respect to wild animals and forest officials [46], as well as males being more likely to harvest NTFPs for trade [47].

The far greater numbers of pilgrims in $\mathrm{MMH}$ compared to the other two sites underpins the much higher harvesting frequency at $\mathrm{MMH}$, with almost half of them going out daily. This may also be possible because of the almost double the density of trees in $\mathrm{MMH}$ than at either of the other two sites [39], in both harvested and unharvested areas. This is likely to be a consequence of MMH having large areas (65\%) of dry deciduous forests [48] which is where B. serrata is most common. Additionally, in BRT, the availability of other kinds of gum-resin used by the Soliga tribes is high [49], thereby reducing the demand for $B$. serrata gum-resin.

It is unclear if the higher demand in $\mathrm{MMH}$ is what underlies the widespread collection of deadwood and bark scale forms of B. serrata gum-resin. In other words, perhaps there is insufficient production of pure forms, which has led to the collection of less pure forms. While the harvesting of deadwood and bark scales may appear to be ecologically more benign than removing bark strips or making incisions to induce gum-resin flows, some indicators suggest that the MMH populations are under stress. Thus, although tree densities are highest at $\mathrm{MMH}$, the growth rates per tree were the lowest of the three sites, the annual mortality rates were the highest, and the size class distributions suggested erratic recruitment compared to the other sites [39]. Additionally, seedling density was lower at $\mathrm{MMH}$ than the other two sites [39]. While these are all classic indicators of population stress it cannot yet be attributed directly to the nature or intensity of harvesting in $\mathrm{MMH}$, as there are other complicating factors such as changed fire regimes and invasive species [50]. But there is a clear need for further investigation and population monitoring.

The market demand is also shaped by the length of the pilgrimage season at each site. Malai Mahadeshwara Hills draws pilgrims from all over the country and has a higher demand for gum-resin throughout the year. Cauvery Wildlife Sanctuary attracts tourists from the neighboring big cities of Bengaluru and Mysuru for its scenic beauty and pilgrims visiting Muthuraya Swamy temple. On the other hand, BRT restricts pilgrims because it is a tiger reserve [51] and also the market exists only during Biligiri Rangaswamy temple festivities from February to May. The presence of local markets and resource abundance drives the harvest and utilization of any NTFP [52].

The influence of market demand is further evidenced through the average length of time respondents at the three sites had been harvesting gum-resin. Only in BRT, had all the harvesters been harvesting gum-resin either since their childhood or since they started going to the forests, indicating more experience. In contrast, in CWS and MMH more than half of the harvesters had been engaged in the practice for five years or less, which we deem to be a response to growing numbers of pilgrims to the temples, which has attracted new entrants to the trade. Such rapid growth in the number of harvest participants is not unusual among communities with low formal skills and employment and where market demand surges. For example, Shackleton et al. [53] describe the rapid growth in the number of traders in traditional marula beer (Sclerocarya birrea) in northeast South Africa, and Muhwezi et al. [54] reported on the more than three-fold increase in demand for tea baskets made from forest lianas in Uganda. Such rapid growth in the number of harvesters and traders not only reflects increased extraction rates, but also that many of the new participants will have less knowledge on sustainable harvesting practices and sites than those who have been harvesting for decades [55].

The differences in experience, knowledge, and resource availability have shaped very different approaches to gum-resin harvesting in the three sites. At BRT, where commercial demand is the lowest and harvester experience the greatest, most harvesters focus on collecting the pure form of gum-resin, or the pure form mixed with bark. Much of what they harvest is exuded from wounds to the tree from elephants, wind, and humans. The yield from such wounds takes time to accumulate. In 
contrast, in CWS, most harvesters focus on gum-resin produced at ground level or below the soils (from roots) which they have to dig up. They also collect long-horn beetle infested gum-resin. Lastly, in $\mathrm{MMH}$, which has the highest demand and a large proportion of harvesters being relatively new to the practice, the most frequently harvested form is gum-resin in deadwood or bark-scales. These forms yield the greatest weight of product (a mix of gum-resin and wood) in the shortest time, which is perhaps a further evidence of the income imperative driving harvesting practices at this site. The effects of these different harvesting approaches on individual tree vigour and longevity are currently unknown. Wounding of a tree can result in physiological shocks [56], and also offer entry points for pathogens and fungi [57]. In Somalia, making multiple incisions on B. sacra trees and full debarking has led to a drastic decline in the populations [58]. Scraping of bark may alter the resistance of the tree to fire, as might root harvest if the extraction holes are not refilled with soil (which was typically the case). Deadwood removal may perhaps be the least risky, but it could impact on nutrient pools if done on a large scale. Moreover, the effects of harvesting are not solely a result of the type of product or harvesting method, but also the quantities removed and timing in relation to other potential stressors such as herbivory, fire, and invasive species [15]. It is already known that invasive species cover in the three PAs is restricting recruitment of B. serrata [39], as well as population dynamics of other NTFP species [50]. Altered fire regimes have also been implicated in changing the yields of other NTFPs species in the area, such as Phyllanthus [50].

The impact of forest fires on Boswellia species is extensively studied globally [26,59], with general conclusions being that there is a negative relationship. In the current study, awareness among the respondents on the potential negative impacts of fire was evident, although some harvesters believed that fires could enhance the gum-resin productivity. Varghese and Ticktin [60] reported an increase in the gum productivity from Canarium strictum (Burseraceae) when exposed to fire; but trees then had an increased likelihood of death 3-4 years after the fire. A similar understanding of the impact of fire among the harvesters was noticed in our study as well. However, as with harvesting practices, the effects of fire on both gum-resin yield and on tree vigour or mortality will be more nuanced, based on the timing, frequency, and intensity of fires [50,61]. Thus, there is a need for more monitoring and empirical research to differentiate the effects of fire on B. serrata in terms of these measures of fire behavior.

In this paper, we report the production of a different kind of gum-resin from trees infested with longhorn beetles. Our study highlights the existence of greater knowledge on such gum-resin in CWS and limited or no knowledge among the harvesters in BRT and MMH. Negussie et al. [62] suggest immediate management interventions to reduce the economic and ecological loses faced by B. papyrifera populations due to longhorn beetle infestation in Ethiopia. Boswellia serrata is one of the potential hosts for longhorn beetle infestation in the drier woodlands [63]. The knowledge on impact of longhorn beetles on $B$. serrata population in all the study sites was scarce.

We also documented stingless bees (Trigona iridipennis) using B. serrata trees to build their hives and harvesting of the honey by the Soliga communities. The incisions made on the trees to harvest Trigona honey on $B$. serrata trees leads to the production of gum-resin. Trigona iridipennis produce honey that has high medicinal value and is popular among Indian folk medicine [64]. The dimensions of incisions made to harvest this honey are more extensive than any other damage reported. There is a broader research scope to study the impact of longhorn beetles and stingless bees on $B$. serrata population and gum-resin productivity.

The harvesters generally agreed that older trees produce more gum-resin than the younger ones. Boswellia serrata trees attain gum-resin producing capabilities at girth size of approximately $38 \mathrm{~cm}$ [65]. However, some harvesters stated that only the trees with a wound yield gum-resin, which supports the opinion of Tolera et al. [66]. These wounds were not necessarily human induced and could be from a range of different causes as highlighted in our study. Our study reflects a higher degree of damage made by elephants, yielding a higher quantity of gum-resin. 
The findings of this study on gum-resin harvesting practices and knowledge could aid in managing B. serrata stands in its natural habitat across the country. In order to attain conservation goals it is important to link the social-ecological systems framework to the conservation planning; such approaches can help in understanding the human-environment interactions and integration of social considerations [67]. Mainstreaming the concept of social-ecological systems promises several benefits of sustainability [68]. Chunhabunyatip et al. [69] highlight the use of indigenous peoples' beliefs, rituals, and cultures in managing natural resources. Considering the cultural beliefs and practices of Soliga communities in the Western Ghats can contribute in shaping locally relevant and implementable management plans for B. serrata. For example, Samanta and Mandal [70] scientifically validate the indigenous methods of harvesting gum-resin from Commiphora wightii and advocate these methods to help in managing the species populations. Vasishth and Guleria [71] standardized a gum harvesting technique informed by traditional methods of harvesting gum from Sterculia urens that can yield five-times more gum.

\section{Conclusions}

Gum-resin from Boswellia serrata has a high cultural value for Soliga traditional practices and also offers economic returns by selling it at sacred temples frequented by increasing numbers of pilgrims. In comparing harvest practices across the three sites we showed that different forms of gum-resin are harvested, and that form and harvester experience are likely to influence the sustainability of harvests. The diversity of different forms and harvesting approaches poses challenges for the design of harvesting protocols to promote sustainability while maintaining sufficient incomes, and means that harvesting protocols will need to be developed for each site specifically. Nonetheless, the results of this work, in conjunction with the ecological survey results reported by Soumya et al. [39], suggest that current harvesting is sustainable in BRT and CWS, but probably not at MMH. Moreover, enhancement of gum-resin yields after wounding of a tree requires greater examination of the agent and frequency of wounding, as well as tree responses to the nature and extent of wounding. This could be achieved with participation of traditional harvesters who have significant knowledge about what effects the yields of gum-resin and of B. serrata populations generally.

Author Contributions: Conceptualization, K.V.S. and C.M.S.; methodology, K.V.S. and C.M.S.; software, K.V.S.; validation, K.V.S., C.M.S. and S.R.S.; formal analysis, K.V.S. and C.M.S.; investigation, K.V.S.; resources, K.V.S. and S.R.S.; data curation, K.V.S.; writing — original draft preparation, K.V.S.; writing—review and editing, C.M.S.; visualization, C.M.S. and S.R.S.; supervision, C.M.S.; project administration, S.R.S.; funding acquisition, C.M.S. and S.R.S.

Funding: This project was funded by the United States Agency for International Development (USAID; No. AID-386-A-14-00011). The APC was covered by the C.S. contribution made under the auspices of the South African Research Chairs Initiative of the Dept. of Science and Technology and the National Research Foundation (NRF) of South Africa (Grant No. 84379).

Acknowledgments: The authors acknowledge the entomological inputs from Priyadarsanan Dharmarajan at ATREE, Bengaluru. The authors also acknowledge the contributions of ATREE field staff and Karnataka Forest Department for permitting to conduct the study in the protected areas of Karnataka.

Conflicts of Interest: Any opinion, finding, conclusion, or recommendation expressed in this material is that of the authors, and USAID or NRF does not accept any liability in this regard.

\section{References}

1. Angelsen, A.; Jagger, P.; Babigumira, R.; Belcher, B.; Hogarth, N.J.; Bauch, S.; Börner, J.; Smith-Hall, C.; Wunder, S. Environmental Income and Rural Livelihoods: A Global-Comparative Analysis. World Dev. 2014, 64, S12-S28. [CrossRef]

2. Dash, M.; Behera, B. Determinants of Household Collection of Non-Timber Forest Products (NTFPs) and Alternative Livelihood Activities in Similipal Tiger Reserve, India. For. Policy Econ. 2016, 73, 215-228. [CrossRef] 
3. Shackleton, C.M.; Pullanikkatil, D. Considering the Links between Non-Timber Forest Products and Poverty Alleviation. In Poverty Reduction through Non-Timber Forest Products; Springer: Cham, Switzerland, 2019; pp. 15-28.

4. Wunder, S.; Angelsen, A.; Belcher, B. Forests, Livelihoods, and Conservation: Broadening the Empirical Base. World Dev. 2014, 64, S1-S11. [CrossRef]

5. Wunder, S.; Noack, F.; Angelsen, A. Climate, Crops, and Forests: A Pan-Tropical Analysis of Household Income Generation. Environ. Dev. Econ. 2018, 23, 279-297. [CrossRef]

6. Ali, A.; Rahut, D.B. Forest-Based Livelihoods, Income, and Poverty: Empirical Evidence from the Himalayan Region of Rural Pakistan. J. Rural Stud. 2018, 57, 44-54. [CrossRef]

7. Torres, B.; Günter, S.; Acevedo-Cabra, R.; Knoke, T. Livelihood Strategies, Ethnicity and Rural Income: The Case of Migrant Settlers and Indigenous Populations in the Ecuadorian Amazon. For. Policy Econ. 2018, 86, 22-34. [CrossRef]

8. Santika, T.; Wilson, K.A.; Budiharta, S.; Kusworo, A.; Meijaard, E.; Law, E.A.; Friedman, R.; Hutabarat, J.A.; Indrawan, T.P.; St John, F.A. Heterogeneous Impacts of Community Forestry on Forest Conservation and Poverty Alleviation: Evidence from Indonesia. People Nat. 2019, 1, 204-219. [CrossRef]

9. Hiratsuka, M.; Nakama, E.; Satriadi, T.; Fauzi, H.; Aryadi, M.; Morikawa, Y. An Approach to Achieve Sustainable Development Goals Through Participatory Land and Forest Conservation: A Case Study in South Kalimantan Province, Indonesia. J. Sustain. For. 2019, 38, 1-14. [CrossRef]

10. Cocks, M.; López, C.; Dold, T. Cultural Importance of Non-Timber Forest Products: Opportunities They Pose for Bio-Cultural Diversity in Dynamic Societies. In Non-Timber Forest Products in the Global Context; Springer: Berlin/Heidelberg, Germany, 2011; pp. 107-128.

11. Stanley, D.; Voeks, R.; Short, L. Is Non-Timber Forest Product Harvest Sustainable in the Less Developed World? A Systematic Review of the Recent Economic and Ecological Literature. Ethnobiol. Conserv. 2012, 1, 1-39. [CrossRef]

12. Shackleton, C.M.; Pandey, A.K.; Ticktin, T. Ecological Sustainability for Non-Timber Forest Products: Dynamics and Case Studies of Harvesting; Routledge: Abingdon, UK, 2015.

13. Cosiaux, A.; Gardiner, L.M.; Stauffer, F.W.; Bachman, S.P.; Sonké, B.; Baker, W.J.; Couvreur, T.L. Low Extinction Risk for an Important Plant Resource: Conservation Assessments of Continental African Palms (Arecaceae/Palmae). Biol. Conserv. 2018, 221, 323-333. [CrossRef]

14. Gustafson, S.; Cadena, A.J.; Hartman, P. Adaptation Planning in the Lower Mekong Basin: Merging Scientific Data with Local Perspective to Improve Community Resilience to Climate Change. Clim. Dev. 2018, 10, 152-166. [CrossRef]

15. Ticktin, T.; Shackleton, C. Harvesting Non-Timber Forest Products Sustainably: Opportunities and Challenges. In Non-Timber Forest Products in the Global Context; Springer: Berlin/Heidelberg, Germany, 2011; pp. 149-169.

16. Hernández-Barrios, J.C.; Anten, N.P.; Martínez-Ramos, M. Sustainable Harvesting of Non-timber Forest Products Based on Ecological and Economic Criteria. J. Appl. Ecol. 2015, 52, 389-401. [CrossRef]

17. Lopez-Toledo, L.; Perez-Decelis, A.; Macedo-Santana, F.; Cuevas, E.; Endress, B.A. Chronic Leaf Harvesting Reduces Reproductive Success of a Tropical Dry Forest Palm in Northern Mexico. PLoS ONE 2018, 13, e0205178. [CrossRef] [PubMed]

18. Lemenih, M.; Abebe, T.; Olsson, M. Gum and Resin Resources from Some Acacia, Boswellia and Commiphora Species and Their Economic Contributions in Liban, South-East Ethiopia. J. Arid Environ. 2003, 55, 465-482. [CrossRef]

19. Gachathi, F.N.; Eriksen, S. Gums and Resins: The Potential for Supporting Sustainable Adaptation in Kenya's Drylands. Clim. Dev. 2011, 3, 59-70. [CrossRef]

20. Vellema, W.; Mujawamariy, G.; D'Haese, M.; Burger, K. An Economic Approach to Household Collection of Gum Arabic from the Wild. Int. For. Rev. 2013, 15, 255-269. [CrossRef]

21. Mahapatra, A.K.; Tewari, D. Importance of Non-Timber Forest Products in the Economic Valuation of Dry Deciduous Forests of India. For. Policy Econ. 2005, 7, 455-467. [CrossRef]

22. Dejene, T.; Lemenih, M.; Bongers, F. Manage or Convert Boswellia Woodlands? Can Frankincense Production Payoff? J. Arid Environ. 2013, 89, 77-83. [CrossRef]

23. Frank, M.B.; Yang, Q.; Osban, J.; Azzarello, J.T.; Saban, M.R.; Saban, R.; Ashley, R.A.; Welter, J.C.; Fung, K.-M.; Lin, H.-K. Frankincense Oil Derived from Boswellia carteri Induces Tumor Cell Specific Cytotoxicity. BMC Complement. Altern. Med. 2009, 9, 6. [CrossRef] 
24. Hepper, F.N. Arabian and African Frankincense Trees. J. Egypt. Archaeol. 1969, 55, 66-72. [CrossRef]

25. Murthy, T.K.; Shiva, M. Salai Guggul from Boswellia serrata Roxb.-Its Exploitation and Utilization. Indian For. 1977, 103, 466-474.

26. Bongers, F.; Groenendijk, P.; Bekele, T.; Birhane, E.; Damtew, A.; Decuyper, M.; Eshete, A.; Gezahgne, A.; Girma, A.; Khamis, M.A. Frankincense in Peril. Nat. Sustain. 2019, 2, 602-610. [CrossRef]

27. Cocks, M.; Dold, A. The Informal Trade of Cassipourea flanaganii as a Cosmetic in South Africa. In Ethnobiology and Biocultural Diversity: Proceedings of the 7th International Congress of Ethnobiology; University of Georgia Press: Athens, GA, USA, 2004; pp. 412-431.

28. Rijkers, T.; Ogbazghi, W.; Wessel, M.; Bongers, F. The Effect of Tapping for Frankincense on Sexual Reproduction in Boswellia papyrifera. J. Appl. Ecol. 2006, 43, 1188-1195. [CrossRef]

29. Groenendijk, P.; Eshete, A.; Sterck, F.J.; Zuidema, P.A.; Bongers, F. Limitations to Sustainable Frankincense Production: Blocked Regeneration, High Adult Mortality and Declining Populations. J. Appl. Ecol. 2012, 49, 164-173. [CrossRef]

30. Alaamri, M.M.H. Distribution Boswellia sacra in Dhofar Mountains, Sultanate of Oman: Economic Value And. J. Life Sci. 2012, 6, 632.

31. Hassan, B.A.; Glover, E.K.; Luukkanen, O.; Kanninen, M.; Jamnadass, R. Boswellia and Commiphora Species as a Resource Base for Rural Livelihood Security in the Horn of Africa: A Systematic Review. Forests 2019, 10, 551. [CrossRef]

32. Al-Harrasi, A.; Khan, A.L.; Asaf, S.; Al-Rawahi, A. Taxonomy, Distribution and Ecology of Boswellia. In Biology of Genus Boswellia; Springer: Cham, Switzerland, 2019; pp. 11-34.

33. MOE. The National Red List 2012 of Sri Lanka: Conservation Status of the Fauna and Flora; Ministry of Environment: Colombo, Sri Lanka, 2012.

34. Brendler, T.; Brinckmann, J.; Schippmann, U. Sustainable Supply, a Foundation for Natural Product Development: The Case of Indian Frankincense (Boswellia serrata Roxb. Ex Colebr.). J. Ethnopharmacol. 2018, 225, 279-286. [CrossRef]

35. Khan, M.A.; Ali, R.; Parveen, R.; Najmi, A.K.; Ahmad, S. Pharmacological Evidences for Cytotoxic and Antitumor Properties of Boswellic Acids from Boswellia serrata. J. Ethnopharmacol. 2016, 191, 315-323. [CrossRef]

36. Kala, C.P.; Dubey, Y. Anthropogenic Disturbances and Status of Forest and Wildlife in the Dry Deciduous Forests of Chhattisgarh State in India. J. For. Res. 2012, 23, 45-52. [CrossRef]

37. Sunnichan, V.; Mohan Ram, H.; Shivanna, K. Reproductive Biology of Boswellia serrata, the Source of Salai Guggul, an Important Gum-Resin. Bot. J. Linn. Soc. 2005, 147, 73-82. [CrossRef]

38. Seshadri, K.S.; Ganesh, T. Faunal Mortality on Roads Due to Religious Tourism across Time and Space in Protected Areas: A Case Study from South India. For. Ecol. Manag. 2011, 262, 1713-1721. [CrossRef]

39. Soumya, K.V.; Shackleton, C.M.; Setty, S.R. Impacts of Gum-Resin Harvest and Lantana Camara Invasion on the Population Structure and Dynamics of Boswellia serrata in the Western Ghats, India. For. Ecol. Manag. 2019, 453, 117618. [CrossRef]

40. Venkatesh, A.; Veena, N. Mobility Patterns and Gendered Practices among Soliga People in Karnataka, India. In Gender, Mobilities, and Livelihood Transformations; Routledge: Abingdon, UK, 2013; pp. 132-147.

41. Team, R.C. R: A Language and Environment for Statistical Computing; R Foundation for Statistical Computing: Vienna, Austria, 2018.

42. Dunn, O.J. Multiple Comparisons Using Rank Sums. Technometrics 1964, 6, 241-252. [CrossRef]

43. Kothari, A.; Camill, P.; Brown, J. Conservation as If People Also Mattered: Policy and Practice of Community-Based Conservation. Conserv. Soc. 2013, 11, 1.

44. Majumdar, A.; Nusrat, R.; Vungthianmuang, M.; Donnemching, G. Block-1 Tribals of South India; IGNOU: New Delhi, India, 2018.

45. Mandle, L.; Ticktin, T.; Nath, S.; Setty, S.; Varghese, A. A Framework for Considering Ecological Interactions for Common Non-Timber Forest Product Species: A Case Study of Mountain Date Palm (Phoenix loureiroi Kunth) Leaf Harvest in South India. Ecol. Process. 2013, 2, 21. [CrossRef]

46. Venkatesh, A.; Kusakabe, K.; Veena, N. Indigenous People's Response to the Ban on Use of Forest Resources in South India: A Gender Analysis of Governmobility. In Environment Development and Sustainability; Springer Nature Switzerland AG: Basel, Switzerland, 2018; pp. 1-16. 
47. Sunderland, T.; Achdiawan, R.; Angelsen, A.; Babigumira, R.; Ickowitz, A.; Paumgarten, F.; Reyes-García, V.; Shively, G. Challenging Perceptions about Men, Women, and Forest Product Use: A Global Comparative Study. World Dev. 2014, 64, S56-S66. [CrossRef]

48. Aravind, N.; Rao, D.; Ganeshaiah, K.; Shaanker, R.U.; Poulsen, J.G. Impact of the Invasive Plant, Lantana camara, on Bird Assemblages at Male Mahadeshwara Reserve Forest, South India. Trop. Ecol. 2010, 51, 325-338.

49. Si, A. The Traditional Ecological Knowledge of the Solega: A Linguistic Perspective; Springer: Berlin, Germany, 2015.

50. Varghese, A.; Ticktin, T.; Mandle, L.; Nath, S. Assessing the Effects of Multiple Stressors on the Recruitment of Fruit Harvested Trees in a Tropical Dry Forest, Western Ghats, India. PLoS ONE 2015, 10, e0119634. [CrossRef]

51. Swaminathan, D.R. Agricultural Transformation and Indigenous Communities: A Case Study of the Soliga Communities in the Montane Forests, Southern India; Universitäts-und Landesbibliothek Bonn: Bonn, Germany, 2016.

52. Ruiz-Pérez, M.; Belcher, B.; Achdiawan, R.; Alexiades, M.; Aubertin, C.; Caballero, J.; Campbell, B.; Clement, C.; Cunningham, T.; Fantini, A. Markets Drive the Specialization Strategies of Forest Peoples. Ecol. Soc. 2004, 9, 4. [CrossRef]

53. Shackleton, S.; Shanley, P.; Ndoye, O. Invisible but Viable: Recognising Local Markets for Non-Timber Forest Products. Int. For. Rev. 2007, 9, 697-712. [CrossRef]

54. Muhwezi, O.; Cunningham, A.; Bukenya-Ziraba, R. Lianas and Livelihoods: The Role of Fibrous Forest Plants in Food Security and Society around Bwindi Impenetrable National Park, Uganda. Econ. Bot. 2009, 63, 340. [CrossRef]

55. Ballard, H.L.; Huntsinger, L. Salal Harvester Local Ecological Knowledge, Harvest Practices and Understory Management on the Olympic Peninsula, Washington. Hum. Ecol. 2006, 34, 529-547. [CrossRef]

56. Romero, C.; Cunningham, A.; Campbell, B.M.; Luckert, M.K. Bark: Use, Management and Commerce in Africa; New York Botanical Garden Press: New York, NY, USA, 2014.

57. Botha, J.; Witkowski, E.; Shackleton, C. The Impact of Commercial Harvesting on Warburgia salutaris ('Pepper-Bark Tree') in Mpumalanga, South Africa. Biodivers. Conserv. 2004, 13, 1675-1698. [CrossRef]

58. DeCarlo, A.; Ali, S.H. Sustainable Sourcing of Phytochemicals as a Development Tool: The Case of Somaliland's Frankincense Industry; Institute for Environmental Diplomacy and Security, University of Vermont: Burlington, VT, USA, 2014.

59. Eshete, A.; Teketay, D.; Lemenih, M.; Bongers, F. Effects of Resin Tapping and Tree Size on the Purity, Germination and Storage Behavior of Boswellia papyrifera (Del.) Hochst. Seeds from Metema District, Northwestern Ethiopia. For. Ecol. Manag. 2012, 269, 31-36. [CrossRef]

60. Varghese, A.; Ticktin, T. Regional Variation in Non-Timber Forest Product Harvest Strategies, Trade, and Ecological Impacts: The Case of Black Dammar (Canarium strictum Roxb.) Use and Conservation in the Nilgiri Biosphere Reserve, India. Ecol. Soc. 2008, 13, 11. [CrossRef]

61. Mandle, L.; Ticktin, T.; Zuidema, P.A. Resilience of Palm Populations to Disturbance Is Determined by Interactive Effects of Fire, Herbivory and Harvest. J. Ecol. 2015, 103, 1032-1043. [CrossRef]

62. Negussie, A.; Gebrehiwot, K.; Yohannes, M.; Aynekulu, E.; Manjur, B.; Norgrove, L. An Exploratory Survey of Long Horn Beetle Damage on the Dryland Flagship Tree Species Boswellia papyrifera (Del.) Hochst. J. Arid Environ. 2018, 152, 6-11. [CrossRef]

63. Kumawat, M.; Mamocha Singh, K.; Ramamurthy, V. A Checklist of the Long-Horned Beetles (Coleoptera: Cerambycidae) of Arunachal Pradesh, Northeastern India with Several New Reports. J. Threat. Taxa 2015, 7, 7879-7901. [CrossRef]

64. Choudhari, M.K.; Punekar, S.A.; Ranade, R.V.; Paknikar, K.M. Antimicrobial Activity of Stingless Bee (Trigona Sp.) Propolis Used in the Folk Medicine of Western Maharashtra, India. J. Ethnopharmacol. 2012, 141, $363-367$. [CrossRef]

65. Mishra, S.; Behera, N.; Paramanik, T. Comparative Assessment of Gum Yielding Capacities of Boswellia serrata Roxb. and Sterculia urens Roxb. in Relation to Their Girth Sizes. In Proceedings of the International Conference on Anthropogenic Impact on Environment \& Conservation Strategy, Ranchi, India, 2-4 November 2012; pp. 327-330.

66. Tolera, M.; Menger, D.; Sass-Klaassen, U.; Sterck, F.J.; Copini, P.; Bongers, F. Resin Secretory Structures of Boswellia papyrifera and Implications for Frankincense Yield. Ann. Bot. 2012, 111, 61-68. [CrossRef] 
67. Ban, N.C.; Mills, M.; Tam, J.; Hicks, C.C.; Klain, S.; Stoeckl, N.; Bottrill, M.C.; Levine, J.; Pressey, R.L.; Satterfield, T. A Social-Ecological Approach to Conservation Planning: Embedding Social Considerations. Front. Ecol. Environ. 2013, 11, 194-202. [CrossRef]

68. Fischer, J.; Gardner, T.A.; Bennett, E.M.; Balvanera, P.; Biggs, R.; Carpenter, S.; Daw, T.; Folke, C.; Hill, R.; Hughes, T.P. Advancing Sustainability through Mainstreaming a Social-Ecological Systems Perspective. Curr. Opin. Environ. Sustain. 2015, 14, 144-149. [CrossRef]

69. Chunhabunyatip, P.; Sasaki, N.; Grünbühel, C.; Kuwornu, J.; Tsusaka, T. Influence of Indigenous Spiritual Beliefs on Natural Resource Management and Ecological Conservation in Thailand. Sustainability 2018, 10, 2842. [CrossRef]

70. Samanta, J.N.; Mandal, K. Scientific Analysis of Indigenous Techniques for Guggal (Commiphora wightii) Tapping in India. J. For. Res. 2014, 25, 695-700. [CrossRef]

71. Vasishth, A.; Guleria, V. Standardized Gum Tapping Techniques to Maximize Yield from High-Value Indian Tree, Sterculia urens. J. For. Res. 2017, 28, 615-619. [CrossRef]

(C) 2019 by the authors. Licensee MDPI, Basel, Switzerland. This article is an open access article distributed under the terms and conditions of the Creative Commons Attribution (CC BY) license (http://creativecommons.org/licenses/by/4.0/). 